Bielikova Natalia, Dedeliuk Nina. Prerequisites for stretching use in physical education of high school female students. Pedagogy and Psychology of Sport. 2020;6(4):170-174. elSSN 2450-6605. DOI http://dx.doi.org/10.12775/PPS.2020.06.04.016

https://apcz.umk.pl/czasopisma/index.php/PPS/article/view/PPS.2020.06.04.016

https://zenodo.org/record/4591323

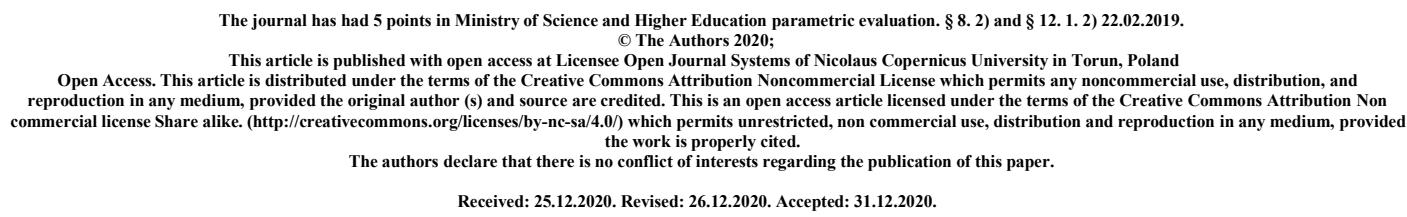

Received: 25.12.2020. Revised: 26.12.2020. Accepted: 31.12.2020.

\title{
PREREQUISITES FOR STRETCHING USE IN PHYSICAL EDUCATION OF HIGH SCHOOL FEMALE STUDENTS
}

\section{Natalia Bielikova, Nina Dedeliuk}

\author{
Lesya Ukrainka Eastern European National University \\ belikova.natalia@vnu.edu.ua \\ https://orcid.org/0000-0003-2789-7586 \\ Lesya Ukrainka Eastern European National University \\ Dedeliuk.Nina@vnu.edu.ua \\ https://orcid.org/0000-0002-9522-5055
}

\begin{abstract}
The article deals with flexibility as one of the leading physical characteristic of a person, presents the scientific view of the types of flexibility and their description, as well as peculiarities of flexibility development at different stages of human life. The paper also covers flexibility development methods using various exercises, including different types of stretching. The author considers the possibilities of stretching use in physical education of secondary schools students in Ukraine.
\end{abstract}

Key words: flexibility, joint mobility, stretching, high school female students. 
Relevance of the topic. Scientists believe that well-being and health of the younger generation is greatly influenced by a number of environmental and socio-economic factors [1, 18]. It is important and highly timely that the system of preventive measures shall integrate an improved daily routine of schoolchildren, systemic physical activity, measures for physical education and body resilience training $[2,17]$. The relevance of the issue under consideration is due to the existing contradictions - between a large number of studies on the physical health of children and adolescents, on the one hand, and the disappointing statistics of the younger generation health, on the other hand; between the need to improve young people physical education and attendance of physical education classes by students. Given the above, it is highly relevant that organization of motor activity of high school female students be studied in order to improve their level of physical fitness and physical qualities.

Research topic: to analyze modern scientific and methodological developments on the possibility of using stretching to develop flexibility of high school female students.

Main research material. Flexibility is one of the five basic physical qualities of a person. Human movements depend on the amplitude of movements that are available in the synovial joints. Modern scientific and methodological works give the following definitions: flexibility is an absolute range of movements in a joint or several joints, or movements with different combinations of joints [3], increased muscle elasticity [4] achieved in dynamic or static conditions by a muscle effort or external forces [5]. There are a number of factors affecting flexibility: the joint shape; compliance (flexibility) of tendons and ligaments; muscles condition and the way they are attached to the joint surface; age, sex, physical activity, physical fitness [6]; functional state of the central nervous system; time of day, environmental conditions and muscular work [7].

There are different approaches to the classification of flexibility. Depending on the work of muscle fibres, the following types of active flexibility are distinguished $[8,9]$ :

- dynamic and kinetic flexibility - the ability to perform dynamic exercises with full (maximum) amplitude of movements in the joint;

- static active flexibility - the ability to accept and maintain a certain position of the body (stretching) thanks to muscle contraction

According to other data [10], there are three types of flexibility:

- static flexibility - the range of joint motion without emphasis on speed (for example, a slow tilt of the torso with the hands touching the floor);

- ballistic flexibility - the range of motion in the joints during hopping, jumping, rhythmic movements;

- dynamic flexibility (syn. functional flexibility) - the range of motion in the joint when engaging in motor activity with normal or high speed.

Certain authors [5] distinguish between general and special flexibility. General flexibility is mobility in all joints of the body which allows one to perform various movements with a large (maximum) amplitude. Special flexibility - maximum mobility only in individual joints which meets the requirements of a particular type of a competitive or professionally applied activity and determines its effectiveness.

Mobility in individual joints as well as flexibility, unlike other qualities, begins to regress from the first years of life. It is caused by cartilage gradual ossification and ligaments decreasing elasticity. Naturally, flexibility increases up to 14-15 years, and in small joints it develops faster than in large ones. The amplitude of movements in the hip joints increases heterochronously up to 13 years. The highest growth rate is observed from 7 to 8 years and from 11 to 13 years, it stabilizes by 16-17 and then has a steady downward trend [5]. The spine joints mobility has a slightly different dynamics. Thus, mobility during unbending significantly increases in boys from 7 to 14 years, and in girls from 7 to 12 years. The spine 
mobility during bending in boys increases significantly at 7-10, and decreases starting from 11-13; girls have the best performance at 14. Later, the spine mobility stabilizes and at the age of 16-17 it begins to deteriorate progressively [11]. Passive flexibility develops most intensively up to 15-17. The sensitive period for passive flexibility development is the age of 9-10, while for active flexibility it is 10-14 years. At the same time, if one does not do any stretching exercises after the age of 13-14, flexibility may start to decrease even at a young age. On the contrary, even at the age of 35-40 after regular classes flexibility improves [10]. Given such age characteristics of the flexibility dynamics, a proper attention should be given to the means of flexibility development and maintaining in the process of schoolchildren physical education.

According to the Physical Education Curriculum for secondary schools of Ukraine, the state requirements to the level of student's general training indicate that students must perform exercises to develop flexibility, speed, agility, endurance, power and speed and strength qualities. In the content section of the training material the following exercises are included to develop flexibility: exercises with a wide amplitude of the arms and legs moves; swing movements; active and passive bending; stretching exercises; exercises with a gymnastic stick or a skipping rope folded in four.

The means of flexibility development include: passive stretching; forced stretching by the coach; swing exercises; stretching with a load; stretching in pairs; spring movements. Flexibility development should go together with power exercises [12].

Depending on the combination of power exercises and stretching exercises, flexibility development has its own characteristics [14]. Thus, to develop active mobility in the joints, the sequence of exercises is recommended: first power exercises, then stretching exercises. Power exercises gradually reduce joints mobility by $20-25 \%$ but after stretching exercises mobility is increased by $50-70 \%$. The method of alternating power exercises and stretching exercises causes step-like changes in joints mobility - a series of power exercises helps to reduce flexibility, while after stretching exercises flexibility increases by $30-35 \%$.

Summarizing a large number of exercises for flexibility development, several groups were defined depending on the work of muscle groups [7, 9]:

- dynamic active exercises - various body bents, rotating, springy, swinging, jerky, jumping movements, movements with the use of weights or various resistances;

- dynamic passive exercises - various movements with the help of external force, using additional resistance or body weight (for example split);

- static active exercises - maintaining a certain body position at close to maximum muscle stretching;

- static passive exercises - maintaining a certain body position with stretching of muscles by external force;

- combined (mixed) exercises - various options of alternating active and passive movements are possible.

Complexes of exercises in the stretching system are aimed at stretching practically all muscles in the body. It should be noted that this wide range of exercises is performed from a variety of starting positions, which is crucial for the effective development of flexibility and mobility in the joints. The method of static stretching involves performing exercises to stretch the muscles until further movements are limited by their own tension, keeping this position for a certain period of time, then muscle relaxation.

Several types of stretching are singled out that can be used to develop the flexibility of high school female students $[9,13,14]$ :

- active - the exercise is performed independently, with a body part gradually moving with a full range of motion; 
- passive (pair, partner) - stretching by means of some external force (the person herself/himself, a partner, a coach, with a weight);

- dynamic - alternately stretching two or more muscle groups by means of slow springy movements, with the position kept at the highest point of stretching for a few seconds;

- ballistic - springy swing movements of the arms and legs, bending and unbending of the torso performed with the maximum amplitude and at a certain pace (due to the increased risk of injury it is recommended to use such exercises in the professional sport);

- static - the exercise is performed in one position, involves slow movements which should result in achieving a certain position of the body or limbs. The time during which the position should be kept varies within 4-6 s, 10-15 s [6], 10-30 s [13,15], 30 $\mathrm{s}$ [14], 15-50 s [16]; 30-60 s [9]. At the beginning stage of classes this time shall be 5 seconds and then gradually increased;

- proprioceptive - when performing the exercise, the muscle that has completely contracted is passively stretched to the maximum possible amplitude of movement in the joint. Then one relaxes the muscles and after a short period of passive rest the exercise is repeated

- deep stretching - begins after static stretching, the muscle is stretched to a greater length; the exercise lasts from 2-3 min to $5 \mathrm{~min}$.

Systematic stretching has been proven to have the following positive effects [9]: increased flexibility, muscle strength and endurance; increased elasticity of muscles, ligaments, and tendons; reduction and prevention of muscle pain; accelerated muscle recovery after intense exercise; better quality warm-up used to prevent injuries and microtraumas; better looks - the body get sculpted, the posture is improved, movements become smooth, the range of joints motion increases, coordination of movements gets better, aging is slowed down due to the increased blood supply, bringing muscles more oxygen and nutrients, lymph circulation is improved; nervous tension is released.

Conclusion. The analysis of scientific and methodological literature on the development of flexibility and the possibilities of stretching use demonstrated the following: high school female students have anatomical and physiological prerequisites for flexibility development; stretching can be used for high school female students flexibility program as it boasts a varied positive impact on joints mobility and body flexibility.

\section{References}

1. Andrijchuk O. General lifestyle characteristics of students who practice sports Journal of Physical Education and Sport. 2016; 16: $699-702$. DOI:10.7752/jpes.2016.s1113

2. Oliinyk Yu.O. Stan zdorovia pidlitkiv-starshoklasnykiv m. Kharkova, shcho meshkaiut u raionakh iz riznymy ekolohichnymy kharakterystykamy. Medytsyna siohodni i zavtra. 2013; (60): 143-146.

3. Galazoulas C. Effects of static stretching duration on isokinetic peak torque in basketball players in semi-professional male basketball players. Journal of Physical Education and Sport, 2016; 16: 1058-1063.

4. Pornpimol M., Juntip N. Effects of stretching and cold-water immersion on functional signs of muscle soreness following plyometric training. Journal of Physical Education and Sport, 2015; 15: 128-135.

5. Haieva S.O., Haievyi V.Yu., Servetnyk A.V. Neobhidnist rozvytku hnuchkosti studentiv spetsialnoii medychnoii hrupy na zaniattiakh z fizychnoho vykhovannia $u$ 
vyshchomy navchalnomy zakladi. Naukovyi chasopys Natsionalnoho pedahohichnoho universytetu imeni M.P. Drahomanova, 2017; 5: 28-31.

6. Jung-Hyun Choi, Kyung-Tae Yoo, Ho-Jung An, Wan-Suk Choi, Ja-Pung Koo, Jae-Ic Kim, Nyeon-Jun Kim, The effects of taping, stretching, and joint exercise on hip joint flexibility and range of motion. J Phys Ther Sci, 2016; 28(5): 1665-1668.

7. Aftimichuk O. The methodology of flexibility development in the teenagers who practice break dance by fitness program. MOJ Sports Med. 2020;4(2):36-39. DOI: 10.15406/mojsm.2020.04.00091

8. Serhiienko L. P. Kompleksne testuvannia rukhovykh zdibnostei liudyny : Navchalnyi posibnyk. Mykolaiv: UDMTU, 2001. 306.

9. Khotimchenko A.V., Burianova A.A., Kolesnikov I.V., Kolesnikova A.P. Ozdorovitelnye tekhnologii $\mathrm{V}$ obuchenii studentov $\mathrm{S}$ ispolzovaniem netraditsionnykh sredstv fizicheskoy kultury: Uchebnoe posobie. Dalnevostochnyi hosudarstvennyi universitet, Khabarovsk. Khabarovsk: Pechatnyy izdatelskiy tsentr DVHHU, 2014. 218.

10. Petrovych V., Alioshyna A. Hnuchkist ta ii vplyv na orhanizm luidyny. Fizychne vykhovannia, sport i kultura zdorovia u suchasnomu suspilstvii: Zbirnyk naukovykh prats. 4 (20), 2012. 319-322.

11. Nikolaiev Yu., Nikolaiev S. Rozvytok hnuchkosti i rukhlyvosti v plechovykh i kulshovykh suhlobakh u yunakiv serednioho ta starshoho shkilnoho viku. Fizychne vykhovannia, sport $i$ kultura zdorovia u suchasnomu suspilstvi : Zbirnyk naukovykh prats, 2013, 2 (22): 86-89.

12. Lapkovskyi E., Yatsiv Ya., Sarabai V. Suchasni vymohy do fizychnoii pidhotovky spetsialistiv. Visnyk Prykarpatskoho universytetu. Fizychna kultura. 2013; 18: 245251.

13. Shevtsiv U., Svistelnyk I., Shyra A. Stretchynh iak odyn iz vydiv ozdorovchoho fitnesu. Problemy aktyvizatsii rekreatsiino-ozdorovchoii diialnosti naselennia: Materialy XI Mizhnarodnoii naukovo-praktychnoii konferentsii. Lviv, 2018: 174177.

14. Putkisto M. Stretching: metod glubokoy roztiazhki. M.: OOO Izdatelskiy dom Sofia, 2003. 175.

15. Page $\mathrm{P}$, Current concepts in muscle stretching for exercise and rehabilitation. Int $J$ Sports Phys Ther, 2012; 7(1): 109-119.

16. Lenyshyn V.A. Udoskonalennia spetsialnoii fizychnoii pidhotovky u hrupovykh vpravakh khudozhnioii himnastyky na etapi spetsializovanoii bazovoii pidhotovky (Dysertatsiia kandydata nauk z fizychnoho vykhovannia ta sportu). Lviv, 2016. 278.

17. Dębski, S.S., Skalski, D., Lizakowski, P., Grygus, I., Stanula, A. (2017). Zdrowotne właściwości zachowań ruchowych - wybrane zagadnienia [Health-related properties of motor behavior - selected issues]. Medycyna $i$ zdrowie. 2:12-44 (in Polish).

18. Zabolotna, O., Skalski, D., Nesterchuk, N., Grygus, I. (2019). Health-related good of physical culture and health education. Reabilitatsiini ta fizkulturno-rekreatsiini aspekty rozvytku liudyny=Rehabilitation \& recreation. Rivne. 5:53-58. 